\title{
Calcium channels - basic aspects of their structure, function and gene encoding; anesthetic action on the channels - a review
}

\author{
[Revue: notions de base sur la structure, la fonction et l'encodage génétique des \\ canaux calciques et action des anesthésiques sur ces canaux]
}

Michiaki Yamakage MD PhD, Akiyoshi Namiki MD PhD

Purpose: To review recent findings concerning $\mathrm{Ca}^{2+}$ channel subtype/structure/function from electrophysiological and molecular biological studies and to explain $\mathrm{Ca}^{2+}$ channel diseases and the actions of anesthetics on $\mathrm{Ca}^{2+}$ channels.

Source: The information was obtained from articles published recently and from our published work.

Principal findings: Voltage-dependent $\mathrm{Ca}^{2+}$ channels serve as one of the important mechanisms for $\mathrm{Ca}^{2+}$ influx into the cells, enabling the regulation of intracellular concentration of free $\mathrm{Ca}^{2+}$. Recent advances both in electrophysiology and in molecular biology have made it possible to observe channel activity directly and to investigate channel functions at molecular levels. The $\mathrm{Ca}^{2+}$ channel can be divided into subtypes according to electrophysiological characteristics, and each subtype has its own gene. The L-type $\mathrm{Ca}^{2+}$ channel is the target of a large number of clinically important drugs, especially dihydropyridines, and binding sites of $\mathrm{Ca}^{2+}$ antagonists have been clarified. The effects of various kinds of anesthetics in a variety of cell types have been demonstrated, and some clinical effects of anesthetics can be explained by the effects on $\mathrm{Ca}^{2+}$ channels. It has recently become apparent that some hereditary diseases such as hypokalemic periodic paralysis result from calcium channelopathies.

Conclusion: Recent advances both in electrophysiology and in molecular biology have made it possible to clarify the $\mathrm{Ca}^{2+}$ channel structures, functions, genes, and the anesthetic actions on the channels in detail. The effects of anesthetics on the $\mathrm{Ca}^{2+}$ channels either of patients with hereditary channelopathies or using gene mutation techniques are left to be discovered.
Objectif : Passer en revue les découvertes récentes concernant le sous-type, la structure et la fonction du canal $\mathrm{Ca}^{2+}$ à partir des études électrophysiologiques et biologiques moléculaires et expliquer les lésions des canaux $\mathrm{Ca}^{2+}$ et les actions des anesthésiques sur ces canaux.

Source: L'information provient d'articles publiés récemment et de nos travaux publiés.

Constatations principales : Les canaux $\mathrm{Ca}^{2+}$ voltage-dépendants sont l'un des importants mécanismes pour le flux entrant de $\mathrm{Ca}^{2+}$ dans les cellules, ce qui facilite la régulation de la concentration intracellulaire de $\mathrm{Ca}^{2+}$ libre. Les progrès récents en électrophysiologie et en biologie moléculaire ont permis d'observer directement l'activité des canaux et d'étudier leurs fonctions au niveau moléculaire. Les canaux $\mathrm{Ca}^{2+}$ peuvent être divisés en sous-types selon les caractéristiques électrophysiologiques et chaque sous-type a son propre gène. Le type $L$ de canal $\mathrm{Ca}^{2+}$ est la cible d'un grand nombre de médicaments importants en clinique, spécialement les dihydropyridines, et les antagonistes des sites de liaison du $\mathrm{Ca}^{2+}$ ont été mis en évidence. Les effets de différentes classes d'anesthésiques dans une diversité de types de cellules ont été démontrés et certains effets cliniques des anesthésiques peuvent être expliqués par les effets sur les canaux $\mathrm{Ca}^{2+}$. Récemment, il est devenu clair que certaines affections héréditaires, comme la paralysie périodique hypokaliémique, résulte de pathologies des canaux calciques.

Conclusion : Les découvertes récentes en électrophysiologie et en biologie moléculaire ont permis de clarifier les structures, fonctions et gènes des canaux $\mathrm{Ca}^{2+}$ et de fournir des détails sur les actions des anesthésiques sur les canaux. II reste à découvrir les effets des anesthésiques sur les canaux $\mathrm{Ca}^{2+}$ des patients atteints de pathologies héréditaires des canaux calciques ou à utiliser des techniques de mutation génétique.

From the Department of Anesthesiology, Sapporo Medical University School of Medicine, Sapporo, Hokkaido, Japan. Address correspondence to: Dr. Michiaki Yamakage, Department of Anesthesiology, Sapporo Medical University School of Medicine, South 1, West 16, Chuo-ku, Sapporo, Hokkaido 060-8543, Japan. Phone: +81-11-611-2111 (ext. 3568); Fax: +81-11-631-9683; E-mail: yamakage@sapmed.ac.jp

Supported in part by 1) grants-in-aid (No. 10770762, 1998 and 12671489, 2000) for research from the Ministry of Education, Science, Sports and Culture; and 2) an incentive grant (No. III-27, 2000) for research from Uehara Memorial Foundation, Tokyo, Japan. Accepted for publication September 12, 2001.

Revision accepted November 16, 2001. 
I $\mathrm{N}$ all types of cells, the calcium ion $\left(\mathrm{Ca}^{2+}\right)$ is an important second messenger for intracellular signal transduction, ${ }^{1}$ while a high concentration of free $\mathrm{Ca}^{2+}$ can also be a cellular toxin as has been demonstrated in ischemic brain damage. The intracellular concentration of free $\mathrm{Ca}^{2+}\left(\left[\mathrm{Ca}^{2+}\right]_{\mathrm{i}}\right)$ is, therefore, precisely controlled at a low level, ${ }^{1,2}$ and each cell/tissue/organ can express its function such as secretion and contraction, leading to memory, movement, pain, etc. In a resting condition, $\left[\mathrm{Ca}^{2}+\right]_{i}$ is maintained at approximately $100 \mathrm{nM}$, which is $1 / 10,000$ of the extracellular concentration of free $\mathrm{Ca}^{2}$ (approximately $1 \mathrm{mM}$ ). There are generally three mechanisms for maintenance of a large gradient of $\mathrm{Ca}^{2}+$ concentrations (Figure. 1). ${ }^{3}$ Those are 1) the cell membrane, which consists of a $\mathrm{Ca}^{2}{ }^{+}$-impermeable lipid bilayer; 2 ) powerful systems to excrete $\mathrm{Ca}^{2+}$ outside to the extracellular space $\left[\mathrm{Ca}^{2+}\right.$ pump ( $\mathrm{Ca}^{2+}-\mathrm{nH}^{+}$ATPase) and $\mathrm{Na}^{+}-\mathrm{Ca}^{2+}$ exchanger]; and 3) intracellular organelles such as endoplasmic reticulum and mitochondria for the $\mathrm{Ca}^{2+}$ uptake. ${ }^{3}$

Cell function is determined by the balance of activator and inhibitor mechanisms that, in turn, are mediated by receptors and channels on the surfaces of cells. ${ }^{1,2}$ When the cells are stimulated by some receptor agonists, $\left[\mathrm{Ca}^{2+}\right]_{\mathrm{i}}$ increases from the resting level to approximately $1 \mu \mathrm{M}$, and the increased $\mathrm{Ca}^{2+}$ binds to intracellular substrates (e.g., calmodulin or troponin), leading to modulation of cell function. Skeletal muscle is one of the most well-differentiated organs. Intracellular $\mathrm{Ca}^{2}+$ storing system (i.e., sarcoplasmic reticulum) is highly developed, and quick contraction can be obtained by $\mathrm{Ca}^{2+}$ release from the organelles. In other general cells, an increase in $\left[\mathrm{Ca}^{2+}\right]_{i}$ can be obtained by 1) rapid but transient $\mathrm{Ca}^{2+}$ release from intracellular $\mathrm{Ca}^{2+}$ stores and 2) rather slow $\mathrm{Ca}^{2+}$ influx from the extracellular space. Evidence has shown that $\mathrm{Ca}^{2+}$ influx through $\mathrm{Ca}^{2+}$ channels from the extracellular space is especially important for regulation of $\left[\mathrm{Ca}^{2+}\right]_{i}$, and this evidence is supported, clinically, by the great number of useful $\mathrm{Ca}^{2+}$ antagonists such as dihydropyridines (DHPs). ${ }^{4}$ Recent advances both in electrophysiology $^{5}$ and in molecular biology ${ }^{6}$ have made it possible to observe channel activity directly and to investigate channel functions at molecular levels. Due to these advances, the function of $\mathrm{Ca}^{2+}$ channels, especially voltage-dependent $\mathrm{Ca}^{2+}$ channels (VDCCs), has been clarified in detail, some $\mathrm{Ca}^{2+}$ channelopathies have been described, and direct anesthetic actions on $\mathrm{Ca}^{2}+$ channels have been demonstrated in many kinds of cell types.

The purpose of this review is to briefly summarize recent findings concerning $\mathrm{Ca}^{2+}$ channel subtype/structure/function from electrophysiological and molecular biological studies and to describe $\mathrm{Ca}^{2+}$ channel diseases and the actions of anesthetics on $\mathrm{Ca}^{2+}$ channels. Since

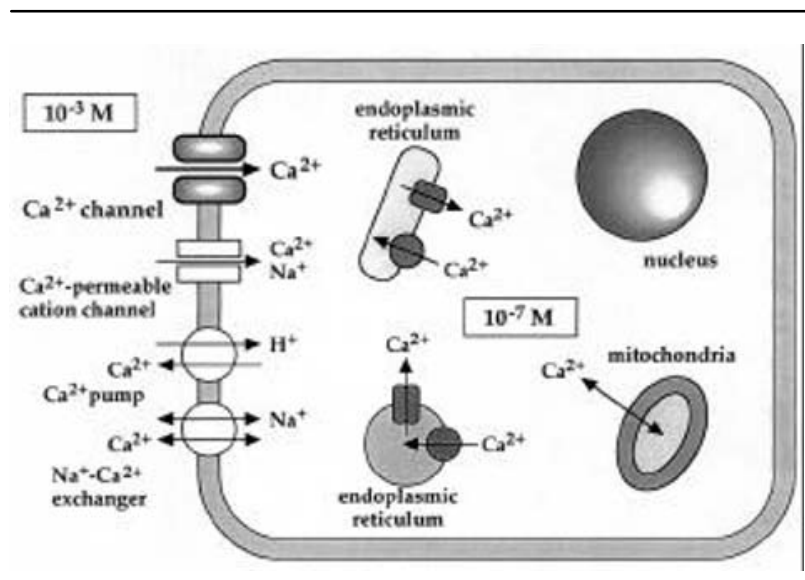

FIGURE 1 Regulation and distribution of intracellular concentration of free $\mathrm{Ca}^{2}$. The increase in intracellular concentration of free $\mathrm{Ca}^{2+}\left(\left[\mathrm{Ca}^{2+}\right]_{\mathrm{i}}\right)$ can be triggered by the release of $\mathrm{Ca}^{2+}$ from intracellular stores, especially the endoplasmic reticulum, and by influx from the extracellular space through voltage-dependent $\mathrm{Ca}^{2+}$ channels (VDCCs) and $\mathrm{Ca}^{2+}$-permeable cation channels.

VDCCs serve as an important mechanism for $\mathrm{Ca}^{2+}$ influx into cells, leading to the regulation of $\left[\mathrm{Ca}^{2+}\right]_{i}$ and cell function, we focus on VDCCs in the following sections.

Electrophysiological characteristics of voltage-depen dent $\mathrm{Ca}^{2}+$ channel subtypes

The possible existence of VDCCs was first reported by Hagiwara et al. . in 1975 using egg cell membrane of a starfish. They suggested that there are distinct $\mathrm{Ca}^{2+}$ channel types with different voltage thresholds for activation and different kinetics for opening and closing. Electrophysiological characteristics were first used to classify $\mathrm{Ca}^{2}+$ channels by the kinetics of opening and closing, and the conductance and lifetime of individual channels (Table I). ${ }^{8}$ They were initially divided into two classes: high-voltage-activated (HVA) and low-voltageactivated (LVA) $\mathrm{Ca}^{2+}$ channels. The threshold activation of $\mathrm{Ca}^{2+}$ currents through HVA $\mathrm{Ca}^{2+}$ channels occurs at $-40 \sim-10 \mathrm{mV}$, while the threshold activation of the currents through LVA channels occurs at lower membrane potentials of $-60 \sim-70 \mathrm{mV}$. HVA Ca ${ }^{2}$ channels are further divided into L-type, N-type, $\mathrm{P} / \mathrm{Q}$-type, and R-type channels, while LVA $\mathrm{Ca}^{2}+$ channels consists of only Ttype channels. R-type is occasionally classified as intermediate-voltage-activated (IVA) channels. Ion selectivity and blocking characteristics of each channel subtype are also shown in Table I. Briefly, $\mathrm{Ba}^{2+}$ has an equal (T-type) or greater (others) ion selectivity over $\mathrm{Ca}^{2}+$ for these VDCCs. $\mathrm{Ni}^{2+}$ and $\mathrm{Cd}^{2+}$ both have a 
TABLE I Electrophysiological classification and characteristics of voltage-dependent $\mathrm{Ca}^{2}{ }^{+}$channels

\begin{tabular}{|c|c|c|c|c|c|}
\hline & T-type & N-type & $L$-type & $P / Q$-type & $R$-type \\
\hline Voltage dependence & LVA & HVA & HVA & HVA & IVA \\
\hline Threshold activation $(\mathrm{mV})$ & -70 & -20 & $-30 \sim-10$ & -60 & -40 \\
\hline Inactivation range $(\mathrm{mV})$ & $-100 \sim-60$ & $-120 \sim-30$ & $-60 \sim-10$ & & \\
\hline Rate of inactivation* (msec) & $20-50$ & $50-80$ & $>500$ & & $20-40$ \\
\hline Single channel conductance (pS) & 8 & 13 & 25 & $10-20$ & 14 \\
\hline Ion selectivity & $\mathrm{Ba}^{2+}=\mathrm{Ca}^{2+}$ & $\mathrm{Ba}^{2+}>\mathrm{Ca}^{2+}$ & $\mathrm{Ba}^{2+}>\mathrm{Ca}^{2+}$ & $\mathrm{Ba}^{2+}>\mathrm{Ca}^{2+}$ & $\mathrm{Ba}^{2+}>\mathrm{Ca}^{2+}$ \\
\hline Blocking by divalent ions & $\mathrm{Ni}^{2+}>\mathrm{Cd}^{2+}$ & $\mathrm{Cd}^{2+}>\mathrm{Ni}^{2+}$ & $\mathrm{Cd}^{2+}>\mathrm{Ni}^{2+}$ & $\mathrm{Ni}^{2+}>\mathrm{Cd}^{2+}$ & \\
\hline Isoform & $1 \mathrm{G}, \quad 1 \mathrm{H}, \quad \mathrm{II}$ & $1 \mathrm{~B}$ & $\begin{array}{l}1 \mathrm{l}, \\
\mathrm{DHP}\end{array}$ & $1 \mathrm{~A}$ & $1 \mathrm{~B}$ \\
\hline Antagonists/blockers & $\begin{array}{l}\text { Mibefradil } \\
\omega \text {-Aga IIIA }\end{array}$ & $\begin{array}{l}\omega \text {-CTX GVIA } \\
\omega \text {-Aga IIIA }\end{array}$ & $\begin{array}{l}\text { PAA } \\
\text { BTZ }\end{array}$ & $\begin{array}{l}\text { FTX } \\
\omega \text {-CTX-MVIIC }\end{array}$ & $\omega$-Aga IIIA \\
\hline
\end{tabular}

LVA=low voltage activated; HVA=high voltage activated; IVA=intermediate voltage activated; *decay time constant; $\mathrm{pS}=$ picosiemens; $\mathrm{DHP}=$ dihydropyridine; PAA=phenylalkylamine; BTZ=benzothiazepine; $\omega$-CTX GVIA $=\omega$-conotoxin GVIA from conus geographus; $\omega$-aga IIIA=-agatoxin IIIA; FTX=funnel spider venom toxin; $\omega$-CTX-MVIIC $=\omega$-conotoxin from conus magus.

blocking effect on most of these VDCCs, and the inhibitory potency on these channels is different for each subtype.

\section{HVA channels}

1) L-type $\mathrm{Ca}^{2+}$ channels: the biophysical properties of L-type currents were first reported for chick dorsal root ganglion neurons in $1985,{ }^{9}$ and L-type VDCCs were shown to be widely distributed in all types of cells except for platelets. In sensory neurons, L-type $\mathrm{Ca}^{2+}$ currents showed a slight inactivation during application of $200-\mathrm{msec}$ depolarization pulses, the decay time constant being higher than $500 \mathrm{msec}$ ("L"ong-lasting). ${ }^{10}$ The current begins to inactivate at holding potentials more positive than $-60 \mathrm{mV}$ and, when elicited from a holding potential of $-60 \mathrm{mV}$, it reaches its maximum amplitude around $+10 \mathrm{mV}$.

2) N-type $\mathrm{Ca}^{2+}$ channels: $\mathrm{N}$-type $\mathrm{Ca}^{2+}$ channels are widely distributed in "N"eurons ("N" either L nor T). In dorsal root ganglion neurons, ${ }^{10,11}$ the $\mathrm{N}$-type channel is distinguished by having a conductance of $13 \mathrm{pS}$, a range of inactivation between -120 and $-30 \mathrm{mV}$, and a decay time constant between 50 and $80 \mathrm{msec}$. In dorsal root ganglion neurons, ${ }^{12}$ the $\mathrm{N}$-type $\mathrm{Ca}^{2+}$ current was isolated from other $\mathrm{Ca}^{2+}$ currents and recorded simply by adjusting the holding potentials and the test potentials. Although $\mathrm{N}$-type $\mathrm{Ca}^{2+}$ currents with various biophysical characteristics have been described, the greatest variety in inactivation rates were reported with range from $100 \mathrm{msec}$ in sympathetic neurons ${ }^{13}$ to 1.5 sec in supraoptic neurons, ${ }^{14}$ when measured in equivalent divalent ion concentrations.

3) P/Q-type $\mathrm{Ca}^{2+}$ channels: this channel, termed "P" because it was first described in "P"urkinje cells in 1989. ${ }^{15}$ P-type $\mathrm{Ca}^{2+}$ currents activate above $-50 \mathrm{mV}$, peak at around $+10 \mathrm{mV}$, and display very little if any inactivation over a period of one second. In contrast to the $\mathrm{N}$-type channel, the P-type channel has a unique monovalent ion selectivity in the absence of divalent cations. The sequence from the most permeable to the least is: $\mathrm{Rb}^{+}>\mathrm{Na}^{+}>\mathrm{K}^{+}>\mathrm{Li}^{+}>\mathrm{Cs}^{+}$. In 1995, Randall and Tsien ${ }^{16}$ reported subsequent designations of the $\mathrm{Q}$-type $\mathrm{Ca}^{2+}$ channel as a separate category. Because $\mathrm{Q}$ - (termed as the following letter of $\mathrm{P}$ ) type current is rapidly inactivated, it requires prior elimination of $\mathrm{P}$ - and $\mathrm{N}$-type $\mathrm{Ca}^{2+}$ current components before it can be studied in isolation.

\section{LVA channels (T-type channels)}

The existence of an LVA $\mathrm{Ca}^{2+}$ current was first discovered in 1981 in neurons of the guinea pig inferior olivary nucleus using intracellular sharp electrodes. ${ }^{17}$ T-type channels start to open with weak depolarizations reaching voltages much more negative than those required to activate other VDCCs, and the currents elicited are "T"ransient. Whole-cell recording from chick and rat dorsal root ganglion neurons has shown that the T-type current is activated at approximately $-50 \mathrm{mV}$ and reaches its maximum value between -40 and $-10 \mathrm{mV}$. Channel inactivation is prevented at very negative potentials, while channel opening is inhibited at a holding potential more positive than $-60 \mathrm{mV}$.

\section{IVA channels (R-type channels)}

R-type (termed as the following letter of $\mathrm{Q}$ or "R"emaining channel) currents are defined as the residual HVA $\mathrm{Ca}^{2+}$ current observed after the application of toxins that selectively block $\mathrm{N}^{-}, \mathrm{L}-, \mathrm{P}-$, and $\mathrm{Q}$-type currents. ${ }^{18}$ The biophysical properties of this current are 


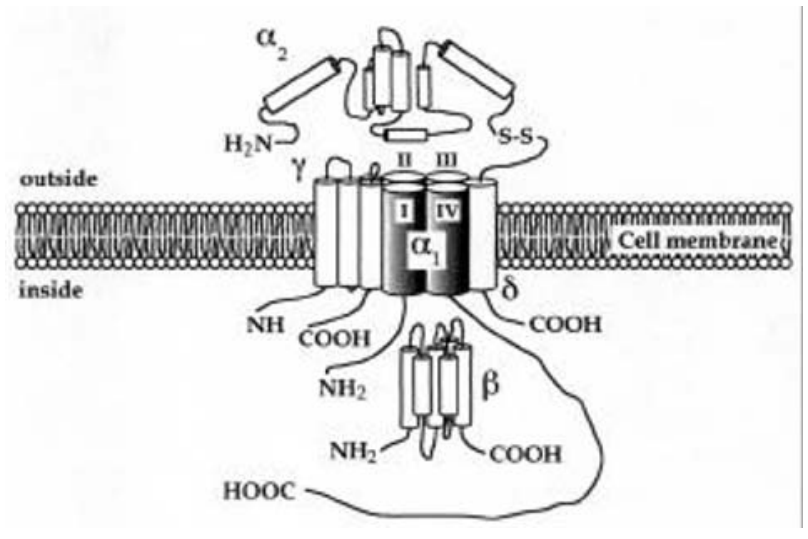

FIGURE 2 Molecular architecture of the L-type voltagedependent $\mathrm{Ca}^{2}+$ channel complex. The central subunit ( $\left.{ }_{1}\right)$ is made up of 24 transmembrane helices, connecting loops, and a large cytoplasmic tail. Auxiliary subunits $\left({ }_{2} / \delta, \beta\right.$, and $\gamma$ ) surround the pore-forming subunit. The helical structures are represented by rods. Connecting loops are drawn as solid lines.

difficult to distinguish from $\mathrm{N}$ and Q-type currents in the whole-cell mode. There are even some parameters that are reminiscent of T-type currents (decay time constant of inactivation: $22 \mathrm{msec}$ at $0 \mathrm{mV}$ ).

$\mathrm{Ca}^{2+}$ channel structure, function, and gene

Structural studies of VDCCs can explain how the channels sense changes in membrane potential and how the pores allow $\mathrm{Ca}^{2+}$ to pass through at a high rate while excluding other cations. Functional studies on single $\mathrm{Ca}^{2+}$ channels and on $\mathrm{Ca}^{2+}$ currents in whole cells have provided clear suggestions about the structure of the voltage sensor, the diameter of the pore, the existence of intrapore binding sites, and the presence of intracellular phosphorylation sites.

\section{Channel structure and function}

1) L-type $\mathrm{Ca}^{2+}$ channels: the molecular structure of the L-type $\mathrm{Ca}^{2+}$ channel has been widely studied in skeletal muscle because of the high concentration of L-type $\mathrm{Ca}^{2+}$ channels in this tissue. ${ }^{19,20}$ Purification and cloning of L- type channels have relied on the use of DHPs. The proposed subunit structure of the skeletal muscle $\mathrm{Ca}^{2+}$ channel is illustrated in Figure $2 .{ }^{21} \mathrm{The}^{2{ }^{2+}}$ channel is composed of five different polypeptide subunits, having different molecular masses: ${ }^{22}$ the 1 subunit $(175 \mathrm{kD})$, which forms the ion channel and contains $\mathrm{Ca}^{2+}$ antagonist binding sites; ${ }^{23,24}$ the ${ }_{2}$ subunit (143 $\mathrm{kD})$, which is associated with 1 and does not contain any high-affinity binding site, ${ }^{2}$ and three low-molecu- lar-weight subunits, $\beta(54 \mathrm{kD}), \gamma(30 \mathrm{kD})$, and $\delta(27$ $\mathrm{kD}) .{ }^{25,26}$ The and $B$ subunits contain phosphorylation sites for cAMP-dependent protein kinase. The ${ }_{2}$, $\gamma$, and $\delta$ subunits are heavily glycosylated, indicating that they have an extracellular face. ${ }^{2} 2$

Four of the five subunits of the skeletal muscle channel have been independently cloned and sequenced: ${ }_{1},{ }^{23,24}{ }_{2},{ }^{24} \beta,{ }^{25}$ and $\gamma .{ }^{26}$ The $a_{1}$ subunit is considered to be the principal structural component of the $\mathrm{Ca}^{2+}$ channel. As with the $\mathrm{Na}^{+}$channel subunit, the $\mathrm{Ca}^{2}+$ channel ${ }_{1}$ subunit possesses four homologous domains that are predicted to span the cell membrane and to contribute to the outer vestibule of the channel pore. Each domain has six putative transmembrane regions (S1, S2 ...S6) (Figure 3). ${ }^{19,23,27}$ Both a short amino-terminal segment and a long carboxy- terminal segment of the 1 subunit are positioned intracellularly. Studies of mutated $\mathrm{Na}^{+}$ channels have revealed that one of the transmembrane segments, S4, serves as the voltage sensor of the channel and is present in all voltage-gated channels. ${ }^{2}{ }^{8}$ The single transmembrane segment of S4 in each motif is distinguished by a collection of repeating positivelycharged amino acids (arginine or lysine), which are located in every third or fourth position. It is these four positively charged transmembrane segments that are believed to comprise the voltage sensor of VDCCs such as $\mathrm{Na}^{+}$and $\mathrm{K}^{+}$channels. ${ }^{29}$

The functions of the L-type $\mathrm{Ca}^{2}+$ channel are related to the generation of action potentials and to signal transduction events at the cell membrane. ${ }^{30}$ L-type VDCCs are expressed ubiquitously in neuronal, endocrine, cardiac, smooth, and skeletal muscle, as well as in fibroblasts and kidney cells. Recent reports suggest a role for L-type VDCCs in the process of neurotransmitter secretion of the central nervous system. ${ }^{31,32}$

2) Other types of VDCCs: N-type VDCCs seem to be heterogeneous, and it is evident that they generate a current that inactivates slowly and can be mistaken for an L-type current. The N-type $\mathrm{Ca}^{2+}$ channel has been purified from the rat brain, ${ }^{33}$ and a thorough purification and reconstruction study has shown that this $\mathrm{Ca}^{2+}$ channel purifies as a complex of four subunits with molecular weights of $230\left({ }_{1}\right), 140\left({ }_{2}\right), 95(\gamma)$, and $57(\beta)$ $\mathrm{kD}$. The N-type VDCC plays a role in some forms of neurotransmitter release. ${ }^{34}$ Direct measurement of $\mathrm{Ca}^{2+}$ currents from the presynaptic terminal region of the chicken ciliary ganglion calyx synapse showed that the predominant $\mathrm{Ca}^{2}+$ channel has pharmacological characteristics similar to those of $\mathrm{N}$-type channels. ${ }^{35}$

The results of immunoblotting have shown that the $\mathrm{P} / \mathrm{Q}$-type $\mathrm{Ca}^{2}+$ channel is composed of $1,{ }_{2} / \delta$, and $B$ subunits. ${ }^{36}$ Immunohistological studies have shown 
TABLE II Voltage-dependent $\mathrm{Ca}^{2}+$ channel ${ }_{1}$ subunit genes.

\begin{tabular}{|c|c|c|c|c|}
\hline Isoform & $\begin{array}{l}\text { Gene name } \\
\text { (HUGO/GBD } \\
\text { nomenclature) }\end{array}$ & $\begin{array}{l}\text { Chromosomal } \\
\text { localization }\end{array}$ & Tissue distribution & $\begin{array}{l}\text { Biophysical } \\
\text { properties }\end{array}$ \\
\hline \multicolumn{5}{|c|}{ High-voltage activated } \\
\hline $1 \mathrm{~A}$ & CACNAIA & $19 \mathrm{pl} 3.1-2$ & $\begin{array}{l}\text { Brain, neuronal cells, } \\
\text { heart }\end{array}$ & P-/Q-type \\
\hline $1 \mathrm{~B}$ & CACNAIB & $9 q 34$ & Brain, neuronal cells & $\mathrm{N}$-type \\
\hline $1 \mathrm{C}$ & CACNAIC & $12 \mathrm{pl} 3.3$ & Ubiquitous & L-type \\
\hline ID & CACNAID & $3 \mathrm{pl} 14.3$ & $\begin{array}{l}\text { Brain, neuronal cells, } \\
\text { endocrine cells }\end{array}$ & L-type \\
\hline $1 \mathrm{~F}$ & CACNAIF & Xpll.23 & & L-type? \\
\hline is & CACNAIS & lq31-q32 & Skeletal muscle & L-type \\
\hline \multicolumn{5}{|c|}{ Intermediate-voltage activated } \\
\hline $1 \mathrm{E}$ & CACNAIE & lq25-q31 & Brain, neuronal cells & R-type \\
\hline \multicolumn{5}{|c|}{ Low-voltage activated } \\
\hline & CACNAIG & $17 \mathrm{q} 22$ & Brain & T-type \\
\hline $\begin{array}{l}1 G \\
1 H\end{array}$ & CACNAIH & $16 \mathrm{p} 13.3$ & Kidney, liver, heart & T-type \\
\hline $1 \mathrm{H}$ & CACNAII & $22 \mathrm{q} 13$ & Brain & T-type \\
\hline
\end{tabular}

that the P/Q-type channel is widely expressed in the mammalian central nervous system and that the channel appears to serve both as a generator of intrinsic activity and as a modulator of neuronal integration and transmitter release.

Because T-type VDCCs are activated at negative membrane potentials close to the resting potential, the T-type channel is thought to be responsible for neuronal oscillatory activity, which is proposed to be involved in processes such as sleep/wakefulness regulation, motor coordination, and neuronal circuit specification during ontogenesis. ${ }^{37}$ In addition, T-type $\mathrm{Ca}^{2+}$ channels are involved in pacemaker activity, lowthreshold $\mathrm{Ca}^{2+}$ spikes, and rebound burst firing. ${ }^{37,38}$ Investigation of the role of T-type channels in other systems (cardiovascular and endocrine systems in particular) has demonstrated that they are abundant in proliferating cells in both normal and pathological conditions. ${ }^{39}$

\section{Channel gene}

Molecular cloning has revealed the existence in humans of at least seven different genes encoding HVA $\mathrm{Ca}^{2+}$ channel ${ }_{1}$ subunits and three LVA Ca ${ }^{2+}$ channel genes (Table II). ${ }^{40}$ Analysis of sequence homology has shown among the 1 subunit cDNAs cloned that there exists considerable base pair homology (77-90\%). In addition, the finding of localization of all, subunit genes on different chromosomes in humans provided further evidence that $\mathrm{Ca}^{2+}$ channels are encoded through a multiple gene family. As new
$\mathrm{Ca}^{2+}$ channel genes are cloned, it is apparent that the alphabetical nomenclatures shown in Table I will overlap at ${ }_{1 \mathrm{~L}}$, which may not mediate an L-type $\mathrm{Ca}^{2}{ }^{+}$current and therefore may create confusion. For these reasons, $\mathrm{Ca}^{2+}$ channels should now be renamed using the chemical symbols of the principal permeating ion (Ca) with the principal physiological regulator (voltage) indicated as a subscript $\left(\mathrm{Ca}_{\mathrm{v}} \mathrm{l}-3\right){ }^{4}{ }^{\mathrm{l}}$

The ${ }_{2} / \delta$ gene has been localized to human chromosome $7 \mathrm{q} 11.23-\mathrm{q} 21.1$ as a single copy gene. ${ }^{42}$ Extensive alternative splicing has been established for the 3'-end of the message, which gives rise to the existence of five separate mRNA species. ${ }^{4}{ }^{3}$ The $\beta$ genes are represented by a multigene family. cDNA cloning has established the existence of at least four genes. Thus far, alternative splicing has been shown for two $B$ genes; therefore, the combination of a number of mature $B$ messages may coexist in various tissues. ${ }^{44}$ The $\gamma$ subunit gene from skeletal muscle has been cloned, and the results of molecular analysis suggest that this transcript is not alternatively spliced. ${ }^{4}$ Similar to the $\mathrm{Na}^{+}$channel, the main subunit ${ }_{1}$ per se can function as $\mathrm{Ca}^{2+}$ channel. Other subunits $\left({ }_{2} / \delta\right.$ and $\left.\beta\right)$ contribute to the regulation of a $\mathrm{Ca}^{2+}$ channel function by changing drug affinity and/or voltage dependence.

$\mathrm{Ca}^{2+}$ channel antagonists and agonists

Although $\mathrm{Ca}^{2+}$ antagonists in a broad sense can include other types of $\mathrm{Ca}^{2+}$ channel antagonists such as $\omega$ - conotoxin $\left(\omega\right.$-CTX) for the $\mathrm{N}$-type $\mathrm{Ca}^{2+}$ chan$\mathrm{nel}^{46}$ and funnel spider venom toxin (FTX) for the P- 
TABLE III $\mathrm{Ca}^{2}+$ channel antagonists and agonists (L-type)

\begin{tabular}{l}
\hline$C a^{2}$ antagonists \\
(1) 1,4 -DIHYDROPYRIDINES \\
nifedipine \\
nicardipine \\
nitrendipine \\
nimodipine \\
nisoldipine \\
felodipine \\
FR34235 \\
PN200-110 \\
(2) PHENYLALKYLAMINES \\
verapamil \\
gallopamil \\
thiapamil \\
(3) BENZOTHIAZEPINES \\
diltiazem \\
YC-170 \\
Bay K 8644 \\
CGP 28392 \\
\hline
\end{tabular}

type $\mathrm{Ca}^{2+}$ channel (Table I), ${ }^{15} \mathrm{Ca}^{2+}$ antagonists in a strict sense mean $\mathrm{L}$-type $\mathrm{Ca}^{2}+$ channel antagonists, especially DHPs.

L-type $\mathrm{Ca}^{2}+$ channel antagonists and agonists (Table III) The L-type $\mathrm{Ca}^{2+}$ channel is the target of a large number of clinically important drugs. $\mathrm{Ca}^{2+}$ antagonists are classified as class IV antiarrhythmic drugs according to the Vaughan-Williams Classification. ${ }^{47}$ The major classes of these drugs are DHPs, phenylalkylamines (PAAs), and benzothiazepines (BTZs), and these compounds are quite different chemically, biochemically, and pharmacologically.

At least six binding sites are believed to exist on the subunit for various kinds of L-type $\mathrm{Ca}^{2}+$ channel antagonists. As shown in Figure 3, the binding sites of the three major types of $\mathrm{Ca}^{2}+$ channel antagonist are different. ${ }^{48}$ Photoaffinity labelling and peptide mapping studies of the skeletal muscle channel have revealed that all three classes bind to the transmembrane region of repeat IV of the subunit with additional sites on repeat III and repeat I for DHPs. ${ }^{4}{ }^{9}$ Three to four amino acids of the IV-S6 segment interact with various $\mathrm{Ca}^{2+}$ channel blockers. DHPs block the native and the expressed cardiac L-type $\mathrm{Ca}^{2}+$ channels, with $\mathrm{nM}$ affinity. The affinity for inhibitory DHPs increases at a depolarized membrane potential, indicating that the voltage-inactivated channel contains the conformation of the high-affinity binding site.

PAAs such as verapamil, gallopamil or thiapamil block the L-type $\mathrm{Ca}^{2+}$ current in a use-dependent

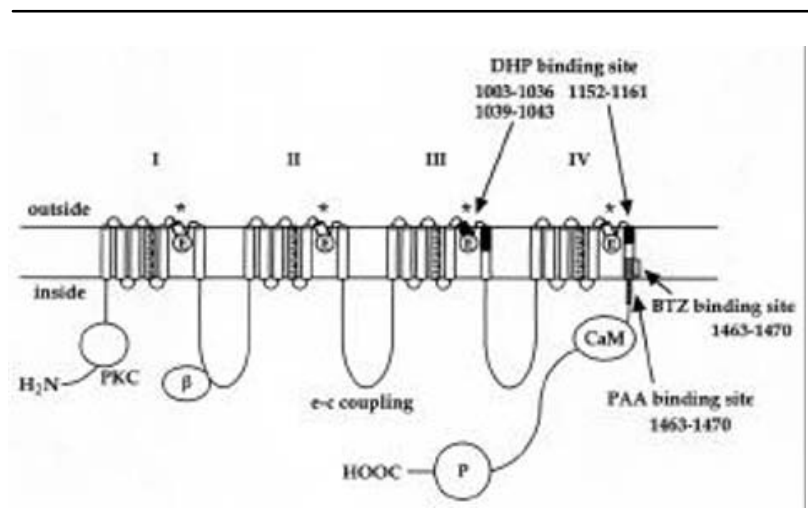

FIGURE 3 Identified structural domains of the ${ }_{10}$ subunit of the L-type $\mathrm{Ca}^{2+}$ channel. I, II, III, and IV, respective repeats of the subunit. $\mathrm{E}=$ glutamate; $\mathrm{P}=$ phosphorylation site of cAMPdependent protein kinase; $\beta=\beta$ subunit interaction site; $\mathrm{CaM}=$ calmodulin interaction site; $\mathrm{e}-\mathrm{c}$ coupling=the II-III loop is responsible for the electrochemical coupling. The SS1-SS2 segments (marked by an asterisk in each motif) line the pore and bear the selectivity filter residues.

manner from the intracellular side of the membrane. ${ }^{50}$ In contrast to PAAs, BTZs access the channel from the extracellular side. Amino acids in the IV-S5 segment proximal to the cytoplasmic mouth of the channel and close to the extracellular mouth of the channel participate in a state-dependent block of the channel by PAAs and BTZs, respectively. ${ }^{5}$

These three kinds of $\mathrm{Ca}^{2}+$ channel antagonists have different inhibitory effects on the cardiovascular system (Table IV). While nifedipine has a greater inhibitory effect on vessels than on the heart, verapamil has a greater inhibitory effect on the heart. That is why nifedipine is used as an antihypertensive drug and verapamil is used for treatment of arrhythmias such as paroxysmal supraventricular arrhythmia. There are two possibilities for the selectivity of DHPs on vessels. First, although there is approximately 95\% homology in channel sequence between ventricular myocytes and vascular smooth muscle cells, the affinity of the ${ }_{1}$ subunit for DHPs is higher in vascular smooth muscle than in the cardiac ventricle. Second, the DHPs have a high affinity for the inactivated state of the $\mathrm{Ca}^{2+}$ channel, and vascular smooth muscle (resting membrane potential: $-50 \sim-60 \mathrm{mV}$ ) has more inactivated channels than do ventricular myocytes (resting membrane potential: $-90 \mathrm{mV}$ ).

Amlodipine $\mathrm{e}^{52}$ and cinildipine ${ }^{53}$ both have inhibitory effects on the $\mathrm{N}$-type $\mathrm{Ca}^{2}{ }^{2}$ channel as well as on the L-type channel. Efonidipine has an inhibitory effect on T- and L-type $\mathrm{Ca}^{2+}$ channels. ${ }^{54}$ The inhibitory 
TABLE IV Inhibitory effects of three kinds of $\mathrm{Ca}^{2}+$ channel antagonists on the cardiovascular systems

\begin{tabular}{llll}
\hline & $\begin{array}{l}\text { Dilatation of vessels } \\
\text { contractility }\end{array}$ & $\begin{array}{l}\text { Inhibition of cardiac } \\
\text { conduction }\end{array}$ & Prolongation of atrial-ventricular \\
\hline Verapamil & ++ & +++ & +++ \\
Diltiazem & ++ & ++ & ++ \\
Nifedipine & +++ & + & 0 \\
\hline
\end{tabular}

TABLE V Calcium channelopathies

\begin{tabular}{|c|c|c|c|c|}
\hline Disorders & $\begin{array}{l}\text { Hereditary } \\
\text { type }\end{array}$ & $\begin{array}{l}\text { Gene name } \\
\text { (HUGO/GBD nomenclature) }\end{array}$ & $\begin{array}{l}\text { Chromosomal } \\
\text { localization }\end{array}$ & Refs \\
\hline \multicolumn{5}{|l|}{ Human } \\
\hline Hypokalemic periodic paralysis & AD & CACNL1A3 (L-type, , 1s) & lq31-32 & 63 \\
\hline Familial hemiplegic migraine & $\mathrm{AD}$ & CACNLIA4 (P/Q-type, IA) & $19 \mathrm{pl} 3.1$ & 64 \\
\hline Episodic ataxia type 2 & $\mathrm{AD}$ & CACNLIA4 (P/Q-type, 1A) & $19 p 13.1$ & 65 \\
\hline Spinocerebellar ataxia type 6 & $\mathrm{AD}$ & CACNLIA4 (P/Q-type, IA) & $19 \mathrm{pl} 3.1$ & 66 \\
\hline Lambert-Eaton myasthenic syndrome & ${ }^{*} 1$ & & $67^{1}$ & \\
\hline Malignant hyperthermia & $\mathrm{AD}$ & ${ }_{2} / \delta * 2$ & $7 \mathrm{q}$ & 68 \\
\hline \multicolumn{5}{|l|}{ Mice } \\
\hline Muscular dysgenesis (mdg) & AR & CACNLlA3 (L-type, is) & $\operatorname{Chr}(\mathrm{F}-\mathrm{G})$ & \\
\hline Tottering and learner phenotypes $(t g)$ & & CACNLlA4 (P/Q-type, 1A) & & \\
\hline Lethargic phenotype $(l h)$ & & CACNB4 $\left(B_{4}\right)$ & & \\
\hline Stargazer (stg) & & CACNG2 (neural-type, $\gamma$ ) & Chr 15 & \\
\hline
\end{tabular}

${ }^{*} 1=$ this disease is characterized by antibodies against these subunits. ${ }^{*} 2=$ malignant hyperthermia is also linked to mutation in the ryanodine receptor $(\mathrm{RYRl}) ; \mathrm{AD}=$ autosomal dominant; $\mathrm{AR}=$ autosomal recessive.

effect on the $\mathrm{N}$-type or T-type $\mathrm{Ca}^{2+}$ channel by these $\mathrm{Ca}^{2+}$ antagonists may bestow an additional clinical advantage for the treatment of hypertension, such as suppression of reflex tachycardia. Another novel $\mathrm{Ca}^{2+}$ channel antagonist, RWJ-22108, has been developed as a bronchoselective $\mathrm{Ca}^{2}+$ entry blocker with potential use as an antiasthmatic agent. ${ }^{55}$ RWJ-22108 relaxes the preconstricted airway in dogs with little effect on blood pressure when administered by aerosol. The inhibition of L-type $\mathrm{Ca}^{2+}$ channels in porcine tracheal smooth muscle cells by RWJ-22108 is qualitatively similar to that by nicardipine but with a greater stabilizing effect on the inactivated channel state. ${ }^{56}$

In contrast to nifedipine-like $\mathrm{Ca}^{2}$ channel antagonists, $\mathrm{Ca}^{2+}$ channel agonistic DHPs have vasoconstricting and positive inotropic properties. ${ }^{57}$ Bay K 8644 has become the prototype of this class. Voltage clamp studies have revealed $\mathrm{Ca}^{2+}$ current increasing effects at $3 \times 10^{-8} \mathrm{M}$ Bay $\mathrm{K} 8644$, while the current is reduced at $3 \times 10^{-6} \mathrm{M}$.

Other types of $\mathrm{Ca}^{2+}$ channel antagonists (Table I) ${ }^{40}$ In sympathetic neurons, ${ }^{58}$ norepinephrine release is controlled by a $\mathrm{Ca}^{2+}$ channel that is sensitive to $\omega$ CTX GVIA and is nitrendipine-resistant. Direct measurement of $\mathrm{Ca}^{2+}$ currents from the presynaptic terminal region of the chicken ciliary ganglion calyx synapse showed that the predominant $\mathrm{Ca}^{2+}$ channel has pharmacological characteristics similar to those of the N-type channel: $:^{35}$ it is resistant to DHPs and is sensitive to $\omega$-CTX GVIA. In a subsequent series of experiments, ${ }^{59,60}$ single-channel analysis of chick sensory neurons, rat sympathetic neurons, and rat pheochromocytoma PCl2 cells showed that -CTX GVIA blocks only the N-type component of the HVA current, leaving the L-type component unaffected.

Direct evidence for the existence of a third type of HVA $\mathrm{Ca}^{2}+$ channel (P-type) in the mammalian central nervous system was provided by the observation of a $\mathrm{Ca}^{2+}$ conductance that is inhibited by a toxin from funnel-web spider poison (FTX) but is not affected by other blockers. ${ }^{15}$ FTX blocks the $\mathrm{Ca}^{2+}$ conductance in cerebellar Purkinje cells and blocks synaptic transmission at the squid giant synapse without affecting the presynaptic action potential. Q-type currents are insensitive to DHPs and to $\omega$-CTX GVIA and potently, but not specifically, blocked by $\omega$-CTX MVIIC. ${ }^{16}$ The Qtype current inactivates and is blocked by $100 \mathrm{nM} \omega$ Aga IVA but requires prior elimination of $\mathrm{P}$ - and $\mathrm{N}$-type $\mathrm{Ca}^{2+}$ current components before it can be studied in isolation. 
$\mathrm{Ni}^{2+}$ sensitivity is not a reliable parameter by which to identify T-type currents because there is a high variability of sensitivity of different expressed, subunits to $\mathrm{Ni}^{2+}$ and L-type channels can also be blocked by $\mathrm{Ni}^{2}+3{ }^{9} \mathrm{New}$ drugs, such as mibefradil, are being proposed as relatively specific $\mathrm{T}$ - and $\mathrm{R}$-type $\mathrm{Ca}^{2+}$ channel blockers, ${ }^{61}$ although further experimentation is required to confirm the selectivity.

Abnormalities of $\mathrm{Ca}^{2+}$ channels $\left(\mathrm{Ca}^{2+}\right.$ channelopathies) The number of identified channelopathies is growing quickly. Their discovery and study are shedding new light on the pathophysiology of many neurological and muscular disorders. Information on the molecular genetics of $\mathrm{Ca}^{2+}$ channels has led to the discovery that alterations in a variety of $\mathrm{Ca}^{2+}$ channel protein complexes are linked to diseases in humans and mice (Table V). ${ }^{62-67}$

Hypokalemic periodic paralysis is an autosomal dominant skeletal muscle disorder manifested by episodic weakness associated with low serum $\mathrm{K}$. Genetic linkage analysis has shown that the gene is localized to chromosome 1q31-32 near a DHP receptor gene. ${ }^{62}$ The principal emphasis for management of anesthesia in patients with familiar periodic paralysis is avoidance of events that will precipitate skeletal muscle weakness. ${ }^{68,69}$ Most other $\mathrm{Ca}^{2+}$ channelopathies include abnormalities of the $\mathrm{P} / \mathrm{Q}$-type $\mathrm{Ca}^{2+}$ channel. It appears that there are no reports on the anesthetic management of, or interaction between, the $\mathrm{Ca}^{2+}$ channelopathies resulting in familial hemiplegic migraine, episodic ataxia type 2 , or spinocerebellar ataxia type 6. Lambert-Eaton myasthenic syndrome (myasthenic syndrome) is characterized by autoantibodies against ${ }_{1 \mathrm{~A}}$ and ${ }_{1 \mathrm{~B}}$ subunits. ${ }^{66}$ Myasthenic syndrome is a rare disorder of neuromuscular transmission most often associated with carcinoma of the lung. ${ }^{7}$ Patients with this syndrome are sensitive to the effects of both depolarizing and nondepolarizing muscle relaxants. The mechanism for this sensitivity is most likely due to a defect in the prejunctional release of acetylcholine. ${ }^{7}$

Malignant hyperthermia susceptibility is an autosomal dominant disorder of skeletal muscle that manifests as a potentially fatal hypermetabolic crisis triggered by commonly used anesthetic agents, especially halothane and suxamethonium. ${ }^{72}$ Abnormality of the ryanodine receptor of the sarcoplasmic reticulum, which is linked to L-type $\mathrm{Ca}^{2}{ }^{+}$channels, seems to be the main cause of this disorder. Approximately half of these disorders seem to be due to ryanodine receptor abnormality. Volatile anesthetics, especially halothane, can activate the abnormal ryanodine recep- tor extremely, resulting in an increase in $\left[\mathrm{Ca}^{2}+\right]_{i}$ and muscle contraction. Although the causes in other cases are not known, Iles et al. ${ }^{67}$ have found one other cause for the disorder $\left({ }_{2} / \delta\right.$ subunits, Table $\left.V\right)$. Indirect molecular genetic methods can be used to demonstrate the inheritance of an abnormal gene in certain family members at risk, and the caffeine-halothane contracture test is also used clinically. ${ }^{72}$ However, as yet, there has been no report on the effects of anesthetics on abnormal L-type $\mathrm{Ca}^{2}+$ channel activity in malignant hyperthermia.

Effects of anesthetics on $\mathrm{Ca}{ }^{2+}$ channel activity A variety of anesthetics have been shown to reduce $\mathrm{Ca}^{2+}$ currents through voltage-dependent $\mathrm{Ca}^{2+}$ channels in several cell types. Most of these results are consistent with the clinical effects of the anesthetics (e.g., cardiac depression and smooth muscle relaxation), and the inhibitory action of the channel is believed to be one of the mechanisms of the anesthetics, especially volatile anesthetics.

\section{Volatile anesthetics}

In the early 1980s, it was believed that volatile anesthetics inhibited $\mathrm{Ca}^{2+}$ entry through membrane-associated VDCCs, because the anesthetics showed inotropic effects on papillary muscle in the guinea $\operatorname{pig}^{73}$ and inhibited nitrendipine binding to $\mathrm{Ca}^{2}{ }^{2}$ channels in the bovine heart. ${ }^{74}$ Ikemoto et al. ${ }^{75}$ first demonstrated in 1985 that halothane decreased inward $\mathrm{Ca}^{2+}$ slow currents in ventricular myocytes in rats, and then Terrar et al. ${ }^{76}$ reported the inhibitory effect of halothane and isoflurane on $\mathrm{Ca}^{2}+$ channels of cardiac myocytes from the guinea pig ventricle. In 1991, investigators simultaneously reported direct inhibitory effects of volatile anesthetics, using patch clamp techniques, on $\mathrm{Ca}^{2}{ }^{2}$ channels in canine ventricular cells, ${ }^{77}$ in canine cardiac Purkinje cells, ${ }^{78}$ in clonal (GH3) pituitary cells, ${ }^{79}$ and in rat sensory neurons. ${ }^{80}$ Following these findings, many investigators have demonstrated inhibitory effects of volatile anesthetics in other kinds of tissues. ${ }^{81-83}$

In general, volatile anesthetics at clinically relevant concentrations inhibit inward currents through voltage- dependent $\mathrm{Ca}^{2+}$ channels in a dose-dependent manner without an apparent change in the time course of activation or inactivation. Volatile anesthetics do not alter the voltage dependence of the currents. Based on the percent anesthetic concentrations in the gas phase, the order of inhibitory potencies for the currents is halothane > isoflurane/enflurane > sevoflurane. Volatile anesthetics also shifted the inactivation curve to a more negative potential, being inter- 
preted as evidence for drug-induced stabilization of the inactivated state. Single channel analysis has shown that halothane decreased the likelihood of channel opening and enhanced the rate at which the channel closed and became inactivated. ${ }^{8} 3$

A series of investigations has been conducted to examine the possible actions of volatile anesthetics on different types of VDCCs, and it has been shown that the activities of both L- and T-types VDCCs in cardiac Purkinje's cells appear to be approximately equally suppressed by halothane, isoflurane, and enflurane. ${ }^{76}$ In clonal (GH3) pituitary cells ${ }^{79}$ and porcine bronchial smooth muscle cells, ${ }^{84}$ however, it has been found that there were different sensitivities to the reductions in T-type and L-type VDCC activities caused by the anesthetics. It has also been reported that N-type VDCCs are insensitive to volatile anesthetics at clinically relevant concentrations. ${ }^{85}$ Recent molecular studies have revealed structural heterogeneity between VDCCs of different tissues, ${ }^{86}$ suggesting that these apparent discrepancies may result from differences in cell types and species and/or experimental conditions employed. Taking these findings into account, there seems to be some information concerning the actions of volatile anesthetics at the level of membrane-associated channels, although it remains to be determined whether the action of the anesthetics on $\mathrm{Ca}^{2+}$ channels is a direct effect on the channel proteins or whether it is a secondary consequence of, for example, alterations in membrane lipids. ${ }^{87}$

Recent studies have revealed that the receptors for inhibitory neurotransmitters such as $\gamma$-aminobutyric acid (GABA) and glycine are sensitive to volatile anesthetics at clinically relevant concentrations. ${ }^{86}$ The functions of $\mathrm{GABA}_{\mathrm{A}}$ and glycine receptors are enhanced by volatile anesthetics, ${ }^{88}$ whereas the activity of the related GABA 1 receptor is reduced. By using chimeric receptor constructs, Mihic et al. ${ }^{89}$ found that a region of 45 amino-acid residues was both necessary and sufficient for the enhancement of the receptor region. Although these observations support the idea that anesthetics exert a specific effect on these ionchannel proteins, this technique has not yet been employed in voltage-dependent $\mathrm{Ca}^{2}{ }^{2}$ channels.

\section{Intravenous anesthetics}

Although most $i v$ anesthetics such as barbiturates and benzodiazepines have their own specific sites of action, these anesthetics also have inhibitory effects on VDCCs in many cell types. Ikemoto et $a l^{75}$ also demonstrated the inhibitory effect of thiamylal on $\mathrm{Ca}^{2+}$ inward currents in rat ventricular cells. Propofol also has significant inhibitory effects on T- and L-type components of the $\mathrm{Ca}^{2+}$ currents in cultured dorsal root ganglion neurons from chick embryos; this inhibition might play a role in cardiovascular side effects observed clinically. ${ }^{90}$ Thiopental, pentobarbital and propofol had little effect on P-type $\mathrm{Ca}^{2+}$ channel activity of cerebellar Purkinje neurons in rats, ${ }^{85}$ suggesting that P-type VDCCs do not play a major role in the induction of general anesthesia. Ketamine in vitro showed inhibitory effects on activation and inactivation of $\mathrm{Ca}^{2+}$ currents of ventricular myocytes in the guinea pig, leading to the direct myocardiac depression. ${ }^{91}$ However, ketamine can support vascular tone and cardiac function presumably secondary to ketamine-induced catecholamine release. The $i v$ anesthetics thiopental, ketamine and propofol all inhibited inward $\mathrm{Ca}^{2+}$ currents through L-type VDCCs of porcine tracheal smooth muscle cells, ${ }^{92}$ demonstrating a cellular effect of these anesthetics that can account for their airway smooth muscle relaxant effects. Thiopental, ketamine, and propofol showed similar effects on activation and inactivation of $\mathrm{Ca}^{2}+$ currents; however, the concentrations required to produce these effects appear to be substantially higher than the free concentrations observed clinically in serum.

Benzodiazepines have their own binding site on the $\mathrm{GABA}_{\mathrm{A}}$ receptor, and the clinical effect of these drugs (e.g., sedation, amnesia and anticonvulsion) may be accounted for by these interactions. ${ }^{93}$ However, there is some evidence that benzodiazepines have inhibitory effects on the cardiovascular system ${ }^{9}$ and a relaxant effect on the airway, ${ }^{95}$ in which there are no benzodiazepine receptors. Diazepam was shown to significantly decrease the inward $\mathrm{Ca}^{2+}$ currents through expressed L-type VDCCs using heart mRNA purified from seven-day-old rats. ${ }^{96}$ Other investigators have also found that benzodiazepines had inhibitory effects on L-type VDCCs in canine myocardial cells, ${ }^{97}$ in canine tracheal smooth muscle cells, ${ }^{98}$ and in porcine intestinal mucosa cells. ${ }^{99}$ Even in neuronal cells, ${ }^{100}$ benzodiazepines have some inhibitory effect on nonGABA-mediated VDCC activity.

\section{Local anesthetics}

Molecular mechanisms of local anesthetics were reviewed in depth by Butterworth and Strichartz in 1990. ${ }^{101}$ It is accepted that local anesthetics inhibit voltage-dependent $\mathrm{Na}^{+}$current of the nerve membrane and, as a result, block nerve impulses responsible for conducting sensory information such as pain or tactile sensation. However, the depressant action of local anesthetics is not exerted selectively on the $\mathrm{Na}^{+}$current Lidocaine at clinically relevant concentrations has been shown to inhibit inward $\mathrm{Ca}^{2+}$ currents in Helix gan- 
glionic neurons ${ }^{102}$ and in frog dorsal root ganglionic cells. ${ }^{103} \mathrm{~A}$ good correlation between local anesthetic potencies to inhibit HVA $\mathrm{Ca}^{2+}$ currents and their anesthetic potencies implies that the inhibition of $\mathrm{Ca}^{2+}$ influx through $\mathrm{L} / \mathrm{N}$-type VDCCs may contribute to spinal anesthesia. Lidocaine, ${ }^{104}$ tetracaine,${ }^{105}$ and bupivacaine $^{106}$ also inhibit the VDCC activity of cardiac myocytes in the chick, guinea pig, and hamster, respectively. The inhibition is characterized by an increase in the time of recovery from inactivation and a negativevoltage shift of the steady-state inactivation curve. The inhibition is voltage-dependent, and the peak amplitude of the $\mathrm{Ca}^{2}+$ current cannot be restored to the control level by washout. The inhibition by local anesthetics of VDCCs in cardiac myocytes might contribute to local anesthetic-induced cardiodepression. ${ }^{107}$

\section{Conclusions}

Intracellular free $\mathrm{Ca}^{2+}$ is important for regulation of cell functions. In all cells except for skeletal smooth muscle cells, increases in concentrations of intracellular free $\mathrm{Ca}^{2+}\left(\left[\mathrm{Ca}^{2}\right]_{\mathrm{i}}\right)$ can be obtained by rapid but transient $\mathrm{Ca}^{2}+$ release from intracellular $\mathrm{Ca}^{2+}$ stores and by slow $\mathrm{Ca}^{2+}$ influx from the extracellular space. Voltage-dependent $\mathrm{Ca}^{2+}$ channels (VDCCs) serve as one of the important mechanisms for $\mathrm{Ca}^{2}+$ influx into the cells, enabling the regulation of $\left[\mathrm{Ca}^{2+}\right]_{i \mathrm{i}}$. Recent advances both in electrophysiology and in molecular biology have made it possible to observe channel activity directly and to investigate channel functions at molecular levels. The $\mathrm{Ca}^{2+}$ channel can be divided into subtypes according to their electrophysiological characteristics, and each subtype is encoded by its own gene. The L-type $\mathrm{Ca}^{2}{ }^{+}$channel is the target of a large number of clinically important drugs, especially dihydropyridines, and binding sites of $\mathrm{Ca}^{2+}$ antagonists have been clarified. The effects of various kinds of anesthetics in a variety of cell types have been demonstrated, and a number of clinical effects of anesthetics can be explained by their effects on $\mathrm{Ca}^{2}+$ channels. It has recently become apparent that hereditary diseases such as hypokalemic periodic paralysis result from calcium channelopathies. However, the effects of anesthetics on the channel activity of patients with hereditary channelopathies have not yet been examined. Further studies will be required to investigate the effects of anesthetics both on VDCCs of the patients with calcium channelopathies and on VDCC subunits with mutation techniques.

\section{References}

1 Somlyo $A P$, Somlyo $A V$. Signal transduction and regulation in smooth muscle. Nature 1994; 372: 231-6.
2 Ghosh A, Greenberg ME. Calcium signaling in neurons: molecular mechanisms and cellular consequences. Science 1995; 268: 239-47.

3 Borle $A B$. Control, modulation, and regulation of cell calcium. Rev Physiol Biochem Pharmacol 1981; 90: 13-153.

4 Poelaert J, Roosens C Perioperative use of dihydropyridine calcium channel blockers. Acta Anaesthesiol Scand 2000; 44: 528-35.

5 Hamill OP, Marty A, Neher E, Sakmann B, Sigworth FJ. Improved patch-clamp techniques for high- resolution current recording from cells and cell-free membrane patches. Pflügers Arch 1981; 391: 85-100.

6 Varadi G, Strobeck M, Koch S, Caglioti L, Zucchi C, Palyi $G$ Molecular elements of ion permeation and selectivity within calcium channels. Crit Rev Biochem Mol Biol 1999; 34: 181-214.

7 Hagiwara S, Ozawa S, Sand O Voltage clamp analysis of two inward current mechanisms in the egg cell membrane of a starfish. J Gen Physiol 1975; 65: 617-44.

8 Reuter $H$ Diversity and function of presynaptic calcium channels in the brain. Curr Opin Neurobiol 1996; 6: 331-7.

9 Nowycky MC, Fox AP, Tsien RW. Three types of neuronal calcium channel with different calcium agonist sensitivity. Nature 1985; 316: 440-3.

10 Fox AP, Nowycky MC, Tsien RW. Kinetic and pharmacological properties distinguishing three types of calcium currents in chick sensory neurones. J Physiol 1987; 394: 149-72.

11 Fox $A P$, Nowycky $M C$, Tsien $R W$. Single-channel recordings of three types of calcium channels in chick sensory neurones. J Physiol 1987; 394: 173-200.

12 Ferroni A, Mancinelli E, Camagni S, Wanke E. Two high voltage-activated calcium currents are present in isolation in adult rat spinal neurons. Biochem Bioph Res Commun 1989; 159: 379-84.

13 Plummer MR, Hess P. Reversible uncoupling of inactivation in N-type calcium channels. Nature 1991; 351: 657-9.

14 Fisher TE, Bourque CW. Distinct-agatoxin-sensitive calcium currents in somata and axon terminals of rat supraoptic neurons. J Physiol 1995; 489(Pt. 2): 383-8.

15 Llinás R, Sugimori M, Lin J-W, Cherksey B. Blocking and isolation of a calcium channel from neurons in mammals and cephalopods utilizing a toxin fraction (FTX) from funnel-web spider poison. Proc Natl Acad Sci USA 1989; 86: 1689-93.

16 Randall $A$, Tsien $R W$. Pharmacological dissection of multiple types of $\mathrm{Ca}^{2+}$ channel currents in rat cerebellar granule neurons. J Neurosci 1995; 15: 2995-3012. 
17 Llinás $R$, Yarom $\Upsilon$. Properties and distribution of ionic conductances generating electroresponsiveness of mammalian inferior olivary neurones in vitro. J Physiol 1981; 315: 569-84.

18 Pearson HA, Sutton KG, Scott RH, Dolphin AC Characterization of $\mathrm{Ca}^{2+}$ channel currents in cultured rat cerebellar granule neurones. J Physiol 1995; 482: 493-509.

19 Catterall WA Structure and function of voltage-sensitive ion channels. Science 1988; 242: 50-61.

20 Fosset M, Jaimovich E, Delpont E, Lazdunski M. $\left[{ }^{3} \mathrm{H}\right]$ Nitrendipine receptors in skeletal muscle. Properties and preferential localization in transverse tubules. J Biol Chem 1983; 258: 6086-92.

21 Varadi G, Mori $\Upsilon$, Mikala G, Schwartz A Molecular determinants of $\mathrm{Ca}^{2}+$ channel function and drug action. Trends Pharmacol Sci 1995; 16: 43-9.

22 Takahashi M, Seager MJ, Jones JF, Reber BFX, Catterall WA Subunit structure of dihydropyridinesensitive calcium channels from skeletal muscle. Proc Natl Acad Sci USA 1987; 84: 5478-82.

23 Tanabe T, Takeshima H, Mikami A, et al. Primary structure of the receptor for calcium channel blockers from skeletal muscle. Nature 1987; 328: 313-8.

24 Ellis SB, Williams ME, Ways NR, et al. Sequence and expression of mRNAs encoding the ${ }_{1}$ and ${ }_{2}$ subunits of a DHP-sensitive calcium channel. Science 1988; 241: 1661-4.

25 Ruth P, Röhrkasten A, Biel M, et al. Primary structure of the $B$ subunit of the DHP-sensitive calcium channel from skeletal muscle. Science 1989; 245: 1115-8.

26 Jay $S D$, Ellis $S B, M c C u e A F$, et al. Primary structure of the $\gamma$ subunit of the DHP-sensitive calcium channel from skeletal muscle. Science 1990; 248: 490-2.

27 Jan LY, Jan $Y N$. Voltage-sensitive ion channels. Cell 1989; 56: 13-25.

28 Stühmer W, Conti F, Suzuki H, et al. Structure parts involved in activation and inactivation of the sodium channel. Nature 1989; 339: 597-603.

29 McCleskey EW, Womack MD, Fieber LA Structural properties of voltage-dependent calcium channels. Int Rev Cytol 1993; 137C: 39-54.

30 Kostyuk PG Diversity of calcium ion channels in cellular membranes. Neuroscience 1989; 28: 253-61.

31 Bonci A, Grillner P, Mercuri NB, Bernardi G L-type calcium channels mediate a slow excitatory synaptic transmission in rat midbrain dopaminergic neurons. J Neurosci 1998; 18: 6693-703.

32 Protti DA, Llano I. Calcium currents and calcium signaling in rod bipolar cells of rat retinal slices. J Neurosci 1998; 18: 3715-24.

33 Witcher DR, De Waard M, Sakamoto J, et al. Subunit identification and reconstitution of the $\mathrm{N}$-type $\mathrm{Ca}^{2+}$ channel complex purified from brain. Science 1993; 261: 486-9.

34 Miller RJ. Multiple calcium channels and neuronal function. Science 1987; 235: 46-52.

35 Stanley EF, Atrakchi AH. Calcium currents recorded from a vertebrate presynaptic nerve terminal are resistant to the dihydropyridine nifedipine. Proc Natl Acad Sci USA 1990; 87: 9683-7.

36 Liu H, De Waard M, Scott VES, Gurnett CA, Lennon $V A$, Campbell KP. Identification of three subunits of the high-affinity $\omega$-conotoxin MVIIC-sensitive $\mathrm{Ca}^{2+}$ channel. J Biol Chem 1996; 271: 13804-10.

37 Llinás $R R$ The intrinsic electrophysiological properties of mammalian neurons: insight into central nervous system function. Science 1988; 242: 1654-64.

38 Avery RB, Jobnston D. Multiple channel types contribute to the low-voltage-activated calcium current in hippocampal CA3 pyramidal neurons. J Neurosci 1996; 16: 5567-82.

39 Ertel SI, Ertel EA Low-voltage-activated T-type $\mathrm{Ca}^{2+}$ channels. TIPS 1997; 18: 37-42.

40 Moreno $\mathrm{DH}$. Molecular and functional diversity of voltage-gated calcium channels. Ann New York Acad Sci 1999; 868: 102-17.

41 Ertel EA, Campbell KP, Harpold MM, et al. Nomenclature of voltage-gated calcium channels (Letter). Neuron 2000; 25: 533-5.

42 Powers PA, Scherer SW, Tsui L-C, Gregg RG, Hogan $K$. Localization of the gene encoding the ${ }_{2} / \delta$ subunit (CACNL2A) of the human skeletal muscle voltage-dependent $\mathrm{Ca}^{2}+$ channel to chromosome 7q21q22 by somatic cell hybrid analysis. Genomics 1994; 19: 192-3.

43 Williams ME, Brust PF, Feldman DH, et al. Structure and functional expression of an -conotoxin- sensitive human N-type calcium channel. Science 1992; 257 : 389-95.

44 Birnbaumer L, Qin N, Olcese R, et al. Structure and functions of calcium channel $B$ subunits. J Bioenerg Biomembr 1998; 30: 357-75.

45 Powers PA, Liu S, Hogan K, Gregg RG Molecular characterization of the gene encoding the subunit of the human skeletal muscle 1,4-dihydropyridine-sensitive $\mathrm{Ca}^{2+}$ channel (CACNLG), cDNA sequence, gene structure, and chromosomal location. J Biol Chem 1993; 268: 9275-9.

46 McCleskey EW, Fox AP, Feldman DH, et al. -

Conotoxin: direct and persistent blockade of specific types of calcium channels in neurons but not muscle. Proc Natl Acad Sci USA 1987; 84: 4327-31.

47 Vaughan Williams EM. Relevance of cellular to clinical electrophysiology in interpreting antiarrhythmic drug action. Am J Cardiol 1989; 64: 5J-9J. 
48 Huber I, Wappl E, Herzog A, et al. Conserved $\mathrm{Ca}^{2+}$ antagonist-binding properties and putative folding structure of a recombinant high-affinity dihydropyridines-binding domain. Biochem J 2000; 347: 829-36.

49 Striessnig J, Grabner M, Mitterdorfer J, Hering S, Sinnegger MJ, Glossmann H. Structural basis of drug binding to $\mathrm{L} \mathrm{Ca}^{2+}$ channels. Trends Pharmacol Sci 1998; 19: 108-15.

50 Trautwein W, Pelzer D, McDonald TF. Interval- and voltage-dependent effects of the calcium channelblocking agents D600 and AQA 39 on mammalian ventricular muscle. Circ Res 1983; 52(suppl. I): 60-8.

51 Motoike HK, Bodi I, Nakayama H, Schwartz A, Veradi $G$ A region in IVS5 of the human cardiac Ltype calcium channel is required for the use-dependent block by phenylalkylamines and benzothiazepines. J Biol Chem 1999; 274: 9409-20.

52 Furukawa T, Nukada T, Suzuki K, et al. Voltage and $\mathrm{pH}$ dependent block of cloned $\mathrm{N}$-type $\mathrm{Ca}^{2+}$ channels by amlodipine. Br J Pharmacol 1997; 121: 1136-40.

53 Fujii S, Kameyama K, Hosono M, Hayashi $\Upsilon$, Kitamura $K$ Effect of cilnidipine, a novel dihydropyridines $\mathrm{Ca}^{++}$-channel antagonist, on $\mathrm{N}$-type $\mathrm{Ca}^{++}$ channel in rat dorsal root ganglion neurons. J Pharmacol Exp Ther 1997; 280: 1184-91.

54 Masumiya H, Shijuku T, Tanaka H, Shigenobu K Inhibition of myocardial L- and T-type $\mathrm{Ca}^{2}{ }^{2}$ currents by efonidipine: possible mechanism for its chronotropic effect. Eur J Pharmacol 1998; 349: 351-7.

55 Ritchie DM, Kirchner T, Moore JB, et al. Experimental antiasthmatic activity of RWJ 22108: a bronchoselective calcium entry blocker. Int Arch Allergy Immunol 1993; 100: 274-82.

56 Yamakage M, Hirshman CA, Namiki A, Croxton CA Inhibition of voltage-dependent $\mathrm{Ca}^{2}{ }^{+}$channels of porcine tracheal smooth muscle by the novel $\mathrm{Ca}^{2}+$ channel antagonist RWJ-22108. Gen Pharmac 1997; 28: 689-94.

57 Bechem M, Schramm M. Calcium-agonists. J Mol Cell Cardiol 1987; 19(Suppl. II): 63-75.

58 Hirning LD, Fox AP, McCleskey EW, et al. Dominant role of $\mathrm{N}$-type $\mathrm{Ca}^{2+}$ channels in evoked release of norepinephrine from sympathetic neurons. Science 1988; 239: 57-61.

59 Plummer MR, Logothetic DE, Hess P. Elementary properties and pharmacological sensitivities of calcium channels in mammalian peripheral neurons. Neuron 1989; 2: 1453-6.

60 Aosaki T, Kasai $H$ Characterization of two kinds of high-voltage-activated Ca-channel currents in chick sensory neurons. Differential sensitivity to dihydropyridines and -conotoxin GVIA. Pflügers Arch 1989; 414: 150-6.

61 Clozel JP, Ertel EA, Ertel SI. Voltage-gated T-type $\mathrm{Ca}^{2+}$ channels and heart failure. Proc Assoc Am Physician 1999; 111: 429-37.

62 Ptàek LJ, Tawil R, Griggs RC, et al. Dihydropyridine receptor mutations cause hypokalemic periodic paralysis. Cell 1994; 77: 863-8.

63 Ophoff RA, Terwindt GM, Vergouwe MN, et al. Familial hemiplegic migraine and episodic ataxia type2 are caused by mutations in the $\mathrm{Ca}^{2+}$ channel gene CACNLlA4. Cell 1996; 87: 543-52.

64 Hess EJ. Migraines in mice? Cell 1996; 87: 1149-51.

65 Zhuchenko O, Bailey J, Bonnen P, et al. Autosomal dominant cerebellar ataxia (SCA6) associated with small polyglutamine expansions in the alpha 1A-voltage-dependent calcium channel. Nat Genet 1997; 15: 62-9.

66 Lennon VA, Kryzer TJ, Griesmann GE, et al. Calcium-channel antibodies in the Lambert-Eaton syndrome and other paraneoplastic syndromes. N Engl J Med 1995; 332: 1467-74.

67 Iles DE, Lehmann-Horn F, Scherer SW, et al. Localization of the gene encoding the ${ }_{2} / \delta$-subunits of the L-type voltage-dependent calcium channel to chromosome $7 q$ and analysis of the segregation of flanking markers in malignant hyperthermia susceptible families. Hum Mol Genet 1994; 3: 969-75.

68 Rollman JE, Dickson CM. Anesthetic management of a patient with hypokalemic familial periodic paralysis for coronary artery bypass surgery. Anesthesiology 1985; 63: 526-7.

69 Robinson JE, Morin VI, Douglas MJ, Wilson RD. Familial hypokalemic periodic paralysis and WolffParkinson-White syndrome in pregnancy. Can J Anesth 2000; 47: 160-4.

70 Wise RP. A myasthenia syndrome complicating bronchial carcinoma. Anaesthesia 1962; 17: 488-90.

71 Agoston S, van Weerden T, Westra P, Broekert A Effects of 4-aminopyridine in Eaton Lambert syndrome. Br J Anaesth 1978; 50: 383-5.

72 Levitt $R C$ Prospects for the diagnosis of malignant hyperthermia susceptibility using molecular genetic approaches. Anesthesiology 1992; 76: 1039-48.

73 Lynch C III, Vogel S, Sperelakis N. Halothane depression of myocardial slow action potential. Anesthesiology 1981; 55: 360-8.

74 Nakao S, Hirata H, Kagawa $\Upsilon$ Effects of volatile anesthetics on cardiac calcium channels. Acta Anaesthesiol Scand 1989; 33: 326-30.

75 Ikemoto $\Upsilon$, Yatani A, Arimura H, Yoshitake J. Reduction of the slow inward current of isolated rat 
ventricular cells by thiamylal and halothane. Acta Anaesthesiol Scand 1985; 29: 583-6.

76 Terrar DA, Victory JGG Isoflurane depresses membrane currents associated with contraction in myocytes isolated from guinea-pig ventricle. Anesthesiology 1988; 69: 742-9.

77 Eskinder H, Rusch NJ, Supan FD, Kampine JP, Bosnjak ZJ. The effects of volatile anesthetics on Land T-type calcium channel currents in canine cardiac Purkinje cells. Anesthesiology 1991; 74: 919-26.

78 Bosnjak ZJ, Supan FD, Rusch NJ. The effects of halothane, enflurane, and isoflurane on calcium current in isolated canine ventricular cells. Anesthesiology 1991; 74: 340-5.

79 Herrington J, Stern RC, Evers AS, Lingle CJ. Halothane inhibits two components of calcium current in clonal (GH3) pituitary cells. J Neurosci 1991; 11: $2226-40$.

80 Takenoshita M, Steinbach JH. Halothane blocks lowvoltage-activated calcium current in rat sensory neurons. J Neurosci 1991; 11: 1404-12.

81 McDowell TS, Pancrazio JJ, Lynch III C Volatile anesthetics reduce low-voltage-activated calcium currents in a thyroid C-cell line. Anesthesiology 1996; 85: 1167-75.

82 ramakage $M$, Hirshman CA, Croxton TL. Volatile anesthetics inhibit voltage-dependent $\mathrm{Ca}^{2}{ }^{+}$channels in porcine tracheal smooth muscle cells. Am J Physiol 1995; 268: L187-91.

83 Nikonorov IM, Blanck TJJ, Recio-Pinto E. The effects of halothane on single human neuronal L-type calcium channels. Anesth Analg 1998; 86: 885-95.

84 Yamakage $M$, Chen X, Tsujiguchi $N$, Kamada $\Upsilon$, Namiki A Different inhibitory effects of volatile anesthetics on T- and L-type voltage-dependent $\mathrm{Ca}^{2+}$ channels in porcine tracheal and bronchial smooth muscles. Anesthesiology 2001; 94: 683-93.

85 Hall AC, Lieb WR, Franks NP. Insensitivity of P-type calcium channels to inhalational and intravenous general anesthetics. Anesthesiology 1994; 81: 117-23.

86 Franks NP, Lieb WR. Molecular and cellular mechanisms of general anaesthesia. Nature 1994; 367: 607-14.

87 Terrar DA Structure and function of calcium channels and the actions of anaesthetics. Br J Anaesth 1993; 71: 39-46.

88 Downie DL, Hall AC, Lieb WR, Franks NP. Effects of inhalational general anaesthetics on native glycine receptors in rat medullary neurones and recombinant glycine receptors in Xenopus oocytes. Br J Pharmacol 1996; 118: 493-502.

89 Mibic SJ, $\Upsilon_{e} Q$ Wick MJ, et al. Sites of alcohol and volatile anaesthetic action on GABA and glycine receptors. Nature 1997; 389: 385-9.
90 Olcese R, Usai C, Maestrone E, Nobile M. The general anesthetic propofol inhibits transmembrane calcium current in chick sensory neurons. Anesth Analg 1994; 78: 955-60.

91 Baum VC, Wetzel GT, Klitzner TS. Effects of halothane and ketamine on activation and inactivation of myocardial calcium current. J Cardiovasc Pharmacol 1994; 23: 799-805.

92 ramakage $M$, Hirshman CA, Croxton TL. Inhibitory effects of thiopental, ketamine, and propofol on voltage-dependent $\mathrm{Ca}^{2+}$ channels in porcine tracheal smooth muscle cells. Anesthesiology 1995; 83: 1274-82.

93 Hevers $W$, Luddens $H$ The diversity of GABA receptors. Pharmacological and electrophysiological properties of GABA channel subtypes. Mol Neurobiol 1998; 18: 35-86.

94 French JF, Rapoport RM, Matlib MA Possible mechanism of benzodiazepine-induced relaxation of vascular smooth muscle. J Cardiovasc Pharmacol 1989; 14: 405-11.

95 Koga $\Upsilon$, Sato S, Sodeyama N, et al. Comparison of the relaxant effects of diazepam, flunitrazepam and midazolam on airway smooth muscle. Br J Anaesth 1992; 69: 65-9.

96 Gershon E. Effect of benzodiazepine ligands on $\mathrm{Ca}^{2+}$ channel currents in Xenopus oocytes injected with rat heart RNA. J Basic Clin Physiol Pharmacol 1992; 3: 81-97.

97 Buljubasic N, Marijic J, Berczi V, Supan DF, Kampine $J P$, Bosnjak ZJ. Differential effects of etomidate, propofol, and midazolam on calcium and potassium channel currents in canine myocardial cells. Anesthesiology 1996; 85: 1092-9.

98 Yamakage M, Matsuzaki T, Tsuj̈guchi N, Honma $\Upsilon$, Namiki $A$ Inhibitory effects of diazepam and midazolam on $\mathrm{Ca}^{2+}$ and $\mathrm{K}^{\mathrm{K}}$ channels in canine tracheal smooth muscle cells. Anesthesiology 1999; 90: 197-207.

99 Yoshida H, Tsunoda $\Upsilon$, Owyang C Diazepam-binding inhibitor ${ }_{33-50}$ elicits $\mathrm{Ca}^{2+}$ oscillation and CCK secretion in STC-1 cells via L-type $\mathrm{Ca}^{2+}$ channels. Am J Physiol 1999; 276: G694-702.

100 Ishizawa $\Upsilon$, Furuya K, Yamagishi S, Dohi S. NonGABAergic effects of midazolam, diazepam and flumazenil on voltage-dependent ion currents in NG108-15 cells. Neuroreport 1997; 8: 2635-8.

101 Butterworth JF, Strichartz GR Molecular mechanisms of local anesthesia: a review. Anesthesiology 1990; 72: 711-34.

102 Akaike N, Ito H, Nishi K, Oyama $\Upsilon$. Further analysis of inhibitory effects of propranolol and local anaesthetics on the calcium current in Helix neurones. Br J Pharmacol 1982; 76: 37-430. 
103 Oyama Y, Sadoshima J-I, Tokutomi N, Akaike N. Some properties of inhibitory action of lidocaine on the $\mathrm{Ca}^{2+}$ current of single isolated frog sensory neurons, Brain Res 1988; 442: 223-8.

104 Josephson IR Lidocaine blocks Na, Ca and K currents of chick ventricular myocytes. J Mol Cell Cardiol 1988; 20: 593-604.

105 Carmeliet E, Morad M, Van der Heyden G, Vereecke J. Electrophysiological effects of tetracaine in single guinea-pig ventricular myocytes. J Physiol (Lond) 1986; 376: 143-61.

106 Rossner KL, Freese KJ. Bupivacaine inhibition of Ltype calcium current in ventricular cardiomyocytes of hamster. Anesthesiology 1997; 87: 926-34.

107 de La Coussaye JE, Bassoul B, Albat B, et al.

Experimental evidence in favor of role of intracellular actions of bupivacaine in myocardial depression. Anesth Analg 1992; 74: 698-702. 